\title{
Faktor-faktor yang Memengaruhi Produksi dan Efektivitas Panen pada Kakao Mulia
}

\section{Factors Affecting Production and Harvesting Effectivity of Edel Cocoa}

\author{
Ariny Jihan Thifany, Edi Santosa*, dan Nurul Khumaida ${ }^{\Theta}$ \\ Departemen Agronomi dan Hortikultura, Fakultas Pertanian, Institut Pertanian Bogor \\ (IPB University), Jl. Meranti, Kampus IPB Darmaga, Bogor 16680, Indonesia
}

Diterima 1 Mei 2020/Disetujui 28 Juli 2020

\begin{abstract}
Low productivity of cocoa (Theobroma cacao L.) in Indonesia is caused by various factors such as improper harvesting practice. The research studied growth, development, and distribution of pod on two edel cocoa clones (DR 2 and DRC 16) and to evaluate factors affecting production and harvesting effectivity. The study was carried out at cocoa farm located at Renteng Plantation, Jember, East Java, Indonesia in January-May 2019. Pod growth, distribution, and disease incidents were evaluated on the stem $0-200 \mathrm{~cm}$ from soil level. The results showed that harvested pod met $73.51 \%$ of the standard quality. DR 2 and DRC 16 matured about 21-24 and 19-22 weeks after anthesis, respectively. Pods distributed predominantly at 151-200 cm above soil surface, and number of pod increased from lower to higher stem. Cocoa production was affected by clone, fruit position on the stem height, pest and disease infections, and harvester's age and their height. In order to increase cocoa production, it is important to increase harvesting effectivity by managing fruit position such as maintaining tree height to fit with harvester's age and height.
\end{abstract}

Keywords: Clone, edel, harvest, productivity, Theobroma cacao

\section{ABSTRAK}

Masih rendahnya produktivitas kakao (Theobroma cacao L.) di Indonesia disebabkan oleh banyak faktor, salah satunya diduga karena teknis pemanenan yang kurang tepat. Penelitian bertujuan mengevaluasi pertumbuhan, perkembangan dan sebaran buah kakao pada batang dari klon DR 2 dan DRC 16 dalam rangka mengkaji faktor yang memengaruhi hasil dan efektivitas panen kakao mulia. Penelitian dilakukan di kebun kakao Perkebunan Renteng, Jember, Jawa Timur, Indonesia pada bulan Januari sampai Mei 2019. Pengamatan karakter meliputi pertumbuhan, sebaran, dan kejadian penyakit buah kakao pada 0-200 cm dari permukaan tanah. Hasil penelitian menunjukkan bahwa kualitas panen memenuhi $73.51 \%$ dari standar. Buah kakao DR 2 dan DRC 16 matang panen berturut-turut pada 21-24 dan 19-22 minggu setelah antesis. Posisi buah terbanyak ada pada ketinggian 151-200 cm dari permukaan tanah, dan jumlah buah meningkat semakin dekat ke kanopi tanaman. Produksi kakao dipengaruhi oleh klon, posisi buah pada pohon, infeksi hama dan penyakit, dan karakteristik pemanen khususnya umur dan tinggi badan. Peningkatan produksi dapat ditempuh melalui peningkatan efektivitas panen melalui pengaturan posisi buah misalnya dengan mempertahankan tinggi pohon agar sesuai dengan keterbatasan umur dan tinggi badan pemanen.

Kata kunci: edel, klon, panen, produktivitas, Theobroma cacao

\section{PENDAHULUAN}

Kakao (Theobroma cacao L.) merupakan komoditas penting penghasil devisa di Indonesia. Pada 2017, luas areal budidaya kakao mencapai 1.7 juta ha, produksi mencapai 0.66 juta ton biji kakao, dan volume ekspor 0.36 juta ton senilai 1.12 miliar USD (BPS, 2018). Indonesia merupakan produsen kakao terbesar ketiga di dunia setelah Pantai

\footnotetext{
* Penulis untuk korespondensi. e-mail: edisang@gmail.com @In memoriam, telah meninggal pada 26 Maret 2020
}

Gading dan Ghana (Al-Ghozy et al., 2017). Budidaya kakao juga menampung lapangan kerja dan menjadi sumber penghasilan petani (Saputra, 2015; Al-Ghozy et al., 2017). Menurut data Badan Pusat Statistik (2018) sebanyak 97.84\% dari total luas areal budidaya kakao adalah perkebunan rakyat.

Produksi kakao di Indonesia berfluktuasi antar tahun (Al-Ghozy et al., 2017). Fluktuasi tersebut disebabkan antara lain oleh kualitas bibit, umur pohon, serangan hama dan penyakit, input produksi, kelembagaan, dan perubahan iklim (Rubiyo dan Siswanto, 2012; Sari et al., 2017; Santosa et al., 2018; Rohman et al., 2019). Menurut Rubiyo dan 
Siswanto (2012) cara panen juga memengaruhi produksi kakao, tetapi hal tersebut masih jarang dikaji. Kakao yang ditanam di lokasi penelitian ini adalah jenis mulia (edel) yakni DR 2, DRC 16 dan DR 38 (PTPN12, 2019). Laman PT Perkebunan Nusantara XII (2019) menyebutkan bahwa kakao mulia adalah varietas criollo, trinitario, dan persilangannya yang membutuhkan sistem budidaya intensif karena produktivitasnya rendah dan rentan serangan hama dan penyakit; tetapi memiliki nilai ekonomi tinggi tinggi karena memiliki rasa enak, warna menarik dan banyak digunakan sebagai makanan, minuman dan kosmetik.

Efektivitas panen diduga dipengaruhi kondisi pohon dan pemanen. Pekerja di kebun kakao umumnya merupakan karyawan harian lepas dan memiliki latar belakang yang beragam (Angela dan Efendi, 2015). Petani kakao biasanya menanam lebih dari satu klon sebagai upaya menekan risiko kegagalan produksi (Santosa et al., 2018), maka petani biasanya menyusun kriteria kemasakan buah sebagai acuan panen bagi pemanen dan pengawas di lapangan. Menurut Anna (2011) tingkat kemasakan buah untuk menghasilkan biji bermutu tinggi minimal adalah $60 \%$, namun menurut Prawoto (2014) tanda-tanda kematangan buah kakao dipengaruhi oleh klon dan faktor lingkungan. Oleh karena itu, pengetahuan terhadap ciri morfologi kematangan buah secara spesifik lokasi merupakan referensi penting bagi pemanen untuk memperoleh buah dengan kemasakan tepat (Rojas et al., 2020).

Secara morfologi, buah kakao tumbuh dan berkembang pada bantalan buah yang terletak pada batang, cabang dan ranting pohon. Pemanen biasanya dilengkapi antel atau cungkring yakni alat panen berbentuk seperti sabit untuk memotong tangkai buah (Anna, 2011). Alat bantu tersebut diperlukan karena pohon kakao umumnya memiliki tinggi minimal 3-4 meter (Angela dan Efendi, 2015). Menurut Randriani et al. (2014) tinggi pohon kakao dipengaruhi oleh klon dan kegiatan pemeliharaan khususnya pemangkasan. Studi sebaran buah kakao kaitannya dengan efektivitas panen masih jarang dilakukan, maka penelitian bertujuan mengkaji faktor-faktor yang mempengaruhi produksi dan efektivitas panen kakao mulia klon DR 2 dan DRC 16 dilihat dari perkembangan dan distribusi buah kakao.

\section{BAHAN DAN METODE}

\section{Lokasi Penelitian}

Penelitian dilaksanakan di Kebun Renteng, PTPN XII, Jember, Jawa Timur, Indonesia (-8.1332674,113.6058446) mulai bulan Januari sampai dengan Mei 2019. Lokasi memiliki tipe iklim B-C menurut Schmidt dan Ferguson dengan 7-8 bulan basah, jenis tanah Latosol dan Aluvial, dan ketinggian tempat $200-400 \mathrm{~m}$ di atas permukaan laut (dpl). Curah hujan rata-rata bulan Januari-Mei pada 10 tahun terakhir $319 \mathrm{~mm}$ (142-430 mm) dengan hari hujan 16 hari (10-21 hari) dan suhu udara rata-rata $23-33{ }^{\circ} \mathrm{C}$.

Pengamatan dilakukan pada klon kakao DR 2 dan DRC 16, yang ditanam pada 2008 dan 2012 atau berumur 11 dan 7 tahun. Setiap klon diamati pada 3 blok yang merepresentasikan ulangan, mengikuti standar analisis untuk taksasi produksi (Prawoto, 2014). Pohon dikelola sesuai standar good agricultural practices (GAP). Pohon penaungan tetap adalah kelapa dan lamtoro. Populasi kakao per ha adalah 952 untuk DR 2 dan 1,111 untuk klon DRC 16.

\section{Pertumbuhan dan Perkembangan Buah}

Pengamatan dilakukan pada lima pohon contoh dengan tiga ulangan untuk masing-masing klon. Pertumbuhan buah kakao dibagi lima fase (modifikasi dari Rohman et al., 2019), yakni fase 1 (pentil mini; panjang buah 0.5-5.0 $\mathrm{cm}$ ), fase 2 (pentil kecil; panjang 5.1-10.0 cm), fase 3 (buah kecil; panjang 10.1-15.0 cm), fase 4 (buah sedang, panjang 15.1-20.0 cm), dan fase 5 (buah besar, panjang 20.1-masak fisiologis).

Buah pada pohon dipetakan berdasarkan fase pertumbuhannya, dipilih dan diberi label sebagai buah contoh. Awal fase 1, 2, 3, 4, dan 5 secara berturut-turut diwakili oleh buah dengan ukuran $0.5,5.1,10.1,15.1$, dan $20.1 \mathrm{~cm}$. Masing-masing fase dipilih dua buah dan diamati hingga masuk ke fase berikutnya. Sebagai contoh, buah fase 5 dipilih yang memiliki panjang $20.1 \mathrm{~cm}$ dan diamati hingga panen. Pengamatan setiap fase dilakukan setiap minggu meliputi ukuran buah (panjang, diameter dan lingkar), dan warna buah. Panjang buah diukur dari pangkal hingga ujung buah, tanpa mengukur tangkai buah. Pada akhir penelitian, data tersebut lalu digabungkan untuk mendapatkan grafik pertumbuhan buah.

\section{Serangan Hama dan Penyakit}

Jumlah buah terserang hama dan penyakit dihitung dari jejak serangan buah yang masih berada pada pohon. Jejak serangan Helopeltis antonii dan Phytophthora palmivora berdasarkan ciri bekas luka tusukan dan pola busuk. Serangan musang diamati dari bekas gigitan. Hama ulat bulu diamaati dari bekas gigitannya. Pohon yang diamati adalah pohon yang sama dengan pengamatan peubah pertumbuhan buah. Pencatatan data perhitungan serangan hama dan penyakit pada setiap fase dilakukan untuk penambahan serangan hama dan penyakit yang baru.

\section{Sebaran Bantalan dan Buah}

Jumlah bantalan buah, bantalan produktif dan jumlah buah dievaluasi pada 4 ketinggian yaitu: 0-50, 51-100, 101-150, dan 151-200 cm dari permukaan tanah. Bantalan disebut produktif bila menghasilkan buah, tidak menghitung bantalan yang berbunga. Persentase bantalan produktif dihitung dari batalan produktif dibagi dengan total bantalan dikali $100 \%$. Pohon umumnya memiliki jorget setinggi $100 \mathrm{~cm}$, di atas jorget (jorquette) adalah cabang primer dan sekunder. Pengamatan pada peubah ini dilakukan pada umur pohon 7 dan 11 tahun setelah tanam untuk masingmasing klon dengan ulangan sebanyak tiga kali dengan setiap ulangan menggunakan tujuh pohon. Pohon yang 
diamati adalah pohon contoh yang sama dengan pengamatan peubah lain ditambah dengan dua pohon yang ditentukan secara acak.

\section{Tingkat Kehilangan Buah}

Buah diklasifikasikan 'tidak hilang' jika mampu bertahan hingga fase berikutnya. Buah yang gugur atau mati diklasifikasikan 'hilang'; tanpa merinci penyebabnya seperti gangguan fisiologi, hama penyakit dan human error dari pekerja. Tingkat kehilangan dihitung untuk setiap fase. Buah contoh setiap fase adalah tiga dengan lima pohon contoh dan diulang 3 kali. Maka, jumlah contoh yang diamati adalah 450 buah yang berasal dari 5 fase $\mathrm{x} 3$ buah $\mathrm{x}$ 5 pohon x 3 ulangan x 2 klon.

\section{Analisis Panen}

Analisis panen dilakukan pada 10 orang pemanen (semua pemanen wanita) dengan tiga ulangan. Ulangan diperhitungkan dari siklus panen pertama, kedua dan ketiga. Siklus panen dilokasi penelitian adalah 7 hari. Setiap pemanen bertanggungjawab pada areal 3 ha. Buah dianggap berkualitas jika telah masak fisiologis dengan ciri buah berwarna kuning (klon DRC 16) atau merah jingga (klon DR 2) dan jika diketuk berbunyi nyaring. Persentase buah berkualitas dihitung dengan membagi jumlah buah masak fisiologis dibagi dengan total buah yang panen. Tinggi badan pemanen dan usia pemanen juga diamati. Usia pemanen dikelompokkan menjadi berusia $<50$ tahun dan $>50$ tahun.

\section{Analisis Statistik}

Data kuantitatif yakni usia pemanen dan ketepatan panen dianalisis menggunakan ANOVA. Uji kontras data antar dua kelompok pemanen menggunakan uji t-student $\alpha=5 \%$. Korelasi antara tinggi pemanen dengan ketepatan panen dihitung menggunakan 'Pearson correlation' $\alpha=5 \%$ dan $\alpha=10 \%$ untuk menghitung tren menggunakan Minitab 14. Data lain disajikan secara deskriptif.

\section{HASIL DAN PEMBAHASAN}

\section{Pertumbuhan dan Perkembangan Buah}

Klon DRC 16 cenderung lebih cepat panen dibanding DR 2 (Tabel 1). Klon DRC 16 membutuhkan 19-22 minggu sejak pentil siap dipanen sedangkan klon DR 2 membutuhkan 21-24 minggu. Hal ini sejalan dengan pendapat Yusianto dan Firmanto (2015) yang menyatakan buah kakao membutuhkan 20-24 minggu dari berbunga hingga panen, tergantung klon, tingkat pemeliharaan dan lingkungan. Engels et al. (1980) telah membagi klon berdasarkan lama berbunga hingga panen buah yakni singkat (<22 minggu), sedang (22-24 minggu) dan panjang ( $>24$ minggu). Berdasarkan kriteria tersebut, klon DR 2 termasuk kelompok sedang dan DRC 16 termasuk singkat. DR 2 membutuhkan waktu yang lebih lama pada fase 1 dan 5 .
Laju pertumbuhan setiap fase berbeda antar peubah ukuran buah (Tabel 2). Buah memanjang dengan cepat selama fase 2 dan fase 3 pada kedua klon. Diameter dan lingkar buah tumbuh cepat pada fase 3. Secara umum, pertumbuhan buah pada minggu ke-1 hingga ke-7 relatif lambat. Pertumbuhan buah yang cepat dimulai pada minggu ke-8, dan melambat pada minggu ke-15 hingga buah masak. Hal tersebut sejalan dengan pendapat Yusianto dan Firmanto (2015) bahwa buah berkembang lambat pada 40 hari pertama, selanjutnya sangat cepat sampai umur 70 hari, lalu melambat dan diikuti pertumbuhan embrio, akumulasi lemak pada biji, dan pulp mulai melunak pada 30-40 hari sebelum panen.

Tabel 2 menunjukkan bahwa pertumbuhan lingkar buah sangat progresif dibandingkan dengan penambahan panjang dan diamater buah. Hal tersebut terjadi diduga karena permukaan kulit buah pada kedua klon memiliki juringjuring yang menonjol (Gambar 1). Pertumbuhan juring yang progresif diduga terjadi seiring dengan pembesaran ukuran biji. Selama fase 5 laju penambahan panjang dan lingkar buah melambat, tetapi diamater buah masih bertambah dengan kecepatan mendekati pada fase 3. Yusianto dan Firmanto (2015) menyatakan bahwa pertumbuhan cepat buah kakao terjadi hingga 18-20 minggu terkait dengan pembentukan dan pembesaran biji, lalu diikuti dengan perlambatan pertumbuhan mendekati pemasakan buah.

Sejak pentil hingga buah tua, terjadi perubahan warna kulit buah (Tabel 3). Warna dasar setiap fase buah untuk klon DR 2 dan DRC 16 sangat mirip, yakni buah berwarna hijau saat muda dan kuning atau muncul warna kuning-jingga menjelang panen. Perubahan warna kuning atau jingga tersebut menjadi tanda umum buah kakao yang sudah tua (Anna, 2011). Buah dari klon DR 2 dan DRC 16 dianggap telah memasuki fase 4 jika kulit buah menunjukkan warna kemerahan yang kuat (Gambar 1). Terdapat sedikit perbedaan proporsi merah dan hijau saat fase 3 dan 4 pada klon DR 2 dan DRC 16. Kulit buah kakao klon DR 2 memiliki warna semburat kemerahan saat fase 2, namun demikian warna merah kemudian berubah menjadi hijau seiring pertumbuhan dan perkembangan buah. Berdasarkan perubahan morfologi buah yang terjadi selama pertumbuhan dan perkembangan, karakter yang mudah digunakan oleh

Tabel 1. Waktu diperlukan untuk setiap fase perkembangan buah kakao pada klon DR 2 dan DRC 16 di Kebun Renteng, Jember, Jawa Timur

\begin{tabular}{lccc}
\hline Fase & $\begin{array}{c}\text { Panjang buah } \\
(\mathrm{cm})\end{array}$ & \multicolumn{2}{c}{ Waktu (minggu) } \\
\hline 1 & $0.5-5.0$ & $6-7$ & $5-6$ \\
2 & $5.1-10.0$ & 4 & 4 \\
3 & $10.1-15.0$ & 4 & 4 \\
4 & $15.1-20.0$ & $3-4$ & $3-4$ \\
5 & $20.1-$ panen & $4-5$ & $3-4$ \\
\hline & Total & $21-24$ & $19-22$ \\
\hline
\end{tabular}


Tabel 2. Laju penambahan panjang, diameter, dan lingkar buah kakao setiap fase perkembangan buah sampai saat panen di Kebun Renteng, Jember, Jawa Timur

\begin{tabular}{llcccccc}
\hline \multirow{2}{*}{$\begin{array}{l}\text { Peubah } \\
\text { ukuran buah }\end{array}$} & \multirow{2}{*}{ Klon } & \multicolumn{3}{c}{ Rata-rata penambahan per minggu (cm) } & \multicolumn{2}{c}{$\begin{array}{c}\text { Rataan ukuran saat } \\
\text { panen }(\mathrm{cm})\end{array}$} \\
\cline { 3 - 6 } Panjang & DR 2 & Fase 1 & Fase 2 & Fase 3 & Fase 4 & Fase 5 & 24.02 \\
& DRC 16 & 0.782 & 1.189 & 1.158 & 0.724 & 0.337 & 22.95 \\
\multirow{2}{*}{ Diameter $^{z}$} & DR 2 & 0.297 & 0.512 & 0.826 & 0.548 & 0.745 & 10.11 \\
& DRC 16 & 0.319 & 0.588 & 0.692 & 0.471 & 0.433 & 9.64 \\
\multirow{2}{*}{ Lingkar $^{z}$} & DR 2 & 0.987 & 1.615 & 2.010 & 1.382 & 0.912 & 29.50 \\
\hline
\end{tabular}

Keterangan: ${ }^{2}$ Diukur pada bagian terbesar

pemanen untuk menetapkan tingkat kemasakan buah adalah warna kuning-jingga (DR 2) dan hijau-kuning (DRC 16) dengan juring-juring buah yang sudah menojol.

\section{Serangan Hama dan Penyakit}

Penyakit dan hama penting yang ditemukan adalah busuk buah kakao (Phytophthora palmivora) dan kepik penghisap buah (Helopeltis antonii) (Tabel 4). Serangan keduanya pada fase 1-3 menyebabkan banyak buah mati. Penelitian ini dilakukan pada musim penghujan yang merupakan kondisi ideal bagi perkembangan hama dan penyakit tersebut. Helopeltis antonii menyerang buah pada semua fase yakni sebesar 26.67-40.00\% pada klon DR2 dan sebesar 33.33-53.33\% pada klon DRC 16. Buah pentil (fase 1) yang terserang Helopeltis antonii umumnya menjadi layu. Buah muda (fase 2 dan 3) yang terserang Helopeltis antonii jika mampu bertahan akan memiliki kulit retakretak, bentuk buah tidak sempurna dan kerdil sehingga kualitas biji rendah.

Serangan penyakit Phytophthora palmivora terjadi pada semua fase buah, dan tingkat serangan 13.33-33.33\% pada klon DR 2 dan 13.33-26.67\% pada klon DRC 16 (Tabel 4). Tingkat serangan Phytophthora palmivora pada kedua klon termasuk ringan sampai sedang menurut Matitaputty et al. (2014) karena berada pada rentang < $25 \%$ sampai $<50 \%$. Penyakit ini berkembang cepat saat kondisi kebun lembab khususnya selama intensitas hujan yang tinggi. Jamur menyebar melalui percikan air hujan dari satu buah ke buah yang lain. Menurut Atmadja (2003) sporangium Phytophthora palmivora tumbuh cepat dan dapat menginfeksi semua fase buah kakao dalam satu minggu. Buah yang terserang sebelum masuk waktu panen yakni pada fase 1-4, umumnya berakhir dengan kematian.

Serangan ulat bulu sebesar $6.67 \%$ termasuk rendah (Tabel 4). Menurut petugas kebun, intensitas serangan ulat bulu cukup besar biasanya terjadi pada musim kemarau. Serangan hama musang (luwak, Paradoxurus hermaphroditus) sebesar $6.67 \%$ yang terjadi pada fase 3 . Musang adalah binatang malam yang menyukai pulp yang manis yakni pada fase 3,4 , dan 5 .

\section{Tingkat Kehilangan Buah}

Persentase kehilangan buah terbesar pada fase 1-3 (Tabel 5). Rata-rata kehilangan buah pada fase 1 sebesar $70 \%$, diikuti dengan fase 2 sebesar $33.3 \%$ dan fase 3 sebesar 23.3\%. Jumlah kehilangan buah pada fase 3 dari klon DRC 16 lebih tinggi dibandingkan dengan klon DR 2 (Tabel 5), walaupun proporsi buah sehat lebih tinggi pada klon DRC 16 (Tabel 4). Besarnya kehilangan buah pada fase 1-3 diduga karena faktor fisiologis. Menurut Prawoto (2014) kejadian layu pentil meningkat pada pohon kakao yang pada saat bersamaan memiliki banyak buah ukuran sedang
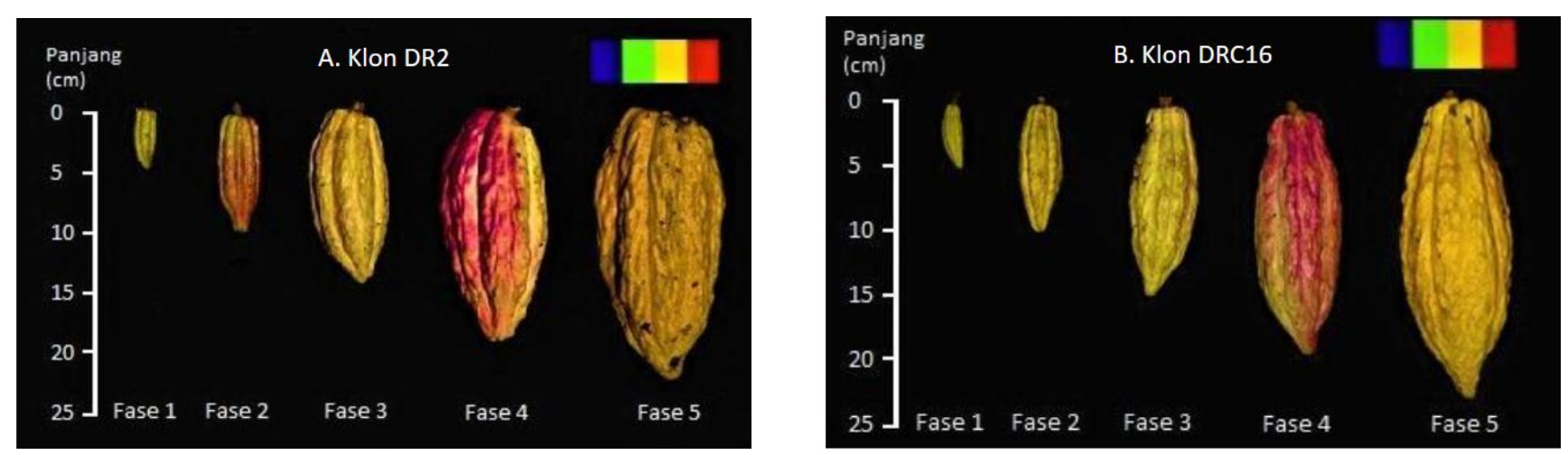

Gambar 1. Penampilan buah kakao setiap fase perkembangan dari klon DR 2 (A) dan DRC 16 (B) di Kebun Renteng, Jember, Jawa Timur 
Tabel 3. Perubahan warna kulit buah kakao klon DR 2 dan DRC 16 di Kebun Renteng, Jember, Jawa Timur

\begin{tabular}{lll}
\hline $\begin{array}{l}\text { Fase buah } \\
\text { (minggu setelah antesis-MSA) }\end{array}$ & \multicolumn{1}{c}{ Klon DR 2 } & Klon DRC 16 \\
\cline { 2 - 3 } Fase 1 (1-7 MSA) & Hijau muda kemerahan & Hijau muda \\
Fase 2 (7-11 MSA) & Hijau muda kemerahan & Hijau muda \\
Fase 3 (11-15 MSA) & Merah muda kehijauan & Hijau muda kemerahan \\
Fase 4 (15-19 MSA) & Merah cerah kehijauan & Hijau muda kemerahan \\
Fase 5 (19-24 MSA) & Merah jingga/merah kekuningan & Hijau kekuningan/merah muda kekuningan \\
\hline
\end{tabular}

dan besar, serta pohon yang sedang membentuk flush. Pada saat penelitian dilaksanakan, sebagian besar tanaman juga memiliki flush. Perbedaan jumlah kehilangan buah antara klon DR 2 dan DRC 16 diduga karena faktor genetik. Namun dugaan tersebut perlu dikaji lebih lanjut.

Persentase kehilangan buah menurun dengan meningkatnya fase buah pada kedua klon (Tabel 5). Kehilangan buah ini sejalan dengan tingginya serangan Phytophthora dan Helopeltis pada Tabel 4. Tingginya kehilangan pada fase 1 dan 2 didominasi oleh serangan hama Helopeltis. Kehilangan buah pada fase 3, 4, dan 5 disebabkan serangan busuk buah. Menurut Tutiliana (2014) pentil yang terserang hama dan penyakit sebagian besar mati. Layu pentil juga dapat terjadi karena sebab lain seperti kekurangan unsur hara mikro Zn dan B (Kurniawati et al., 1998), faktor hormon (Tutiliana, 2014) maupun fisiologi, jenis klon dan musim (Prawoto, 2014).

Kehilangan buah akibat serangan hama Helopeltis antonii rata-rata $36.67 \%$ dan sedangkan akibat penyakit busuk Phytophthora palmivora rata-rata 19.9\% (data tidak ditampilkan). Kematian buah akibat serangan Helopeltis antonii pada DR 2 rata-rata $34.67 \%$ dan pada DRC 16 rata-rata $38.66 \%$. Nilai kehilangan berkebalikan pada serangan Phytophthora palmivora yakni DR 2 lebih tinggi dibandingkan pada DRC 16 yakni secara berturut- turut $24.00 \%$ dan $16.00 \%$. Lokasi kedua klon tersebut berada pada blok yang berdekatan, dengan demikian, kecil kemungkinannya bahwa perbedaan serangan penyakit pada klon tersebut akibat pengaruh faktor lingkungan. Susilo (2014) menyatakan bahwa klon DRC 16 termasuk tahan serangan busuk buah, sedangkan klon DR 2 tidak tahan.

\section{Sebaran Bantalan dan Buah pada Batang}

Buah kakao tumbuh dan berkembang pada bantalan buah. Jumlah bantalan buah rata-rata per pohon klon DR 2 adalah 419 untuk umur 7 tahun dan 361 untuk umur 11 tahun (Tabel 6). Jumlah bantalan rata-rata per pohon klon DRC 16 adalah 359 untuk umur 7 tahun dan 400 bantalan untuk umur 11 tahun. Jumlah total buah per pohon klon DR 2 untuk umur 7 dan 11 tahun masing-masing adalah 44 dan 32 buah, sedangkan pada klon DRC 16 adalah 18 dan 36 buah. Tanpa memperhatikan umur pohon, proporsi bantalan produktif pada klon DR 2 sebesar 7.20-8.59\% dan pada klon DRC 16 sebesar $4.17-7.50 \%$. Bantalan produktif tersebut menghasilkan 1-2 buah, dan sebagian besar hanya memiliki satu buah kakao per bantalan.

Jumlah bantalan buah dan buah meningkat seiring dengan ketinggian posisi dari permukaan tanah (Tabel 6). Semakin mendekati tajuk, jumlah bantalan buah semakin

Tabel 4. Persentase buah kakao sakit dan sehat setiap fase perkembangan pada klon DR 2 dan DRC 16 di Kebun Renteng, Jember, Jawa Timur

\begin{tabular}{|c|c|c|c|c|c|c|}
\hline \multirow{2}{*}{ Klon } & \multirow{2}{*}{ Fase $(n=15)$} & \multicolumn{4}{|c|}{ Buah sakit (\%) } & \multirow{2}{*}{ Buah sehat $(\%)$} \\
\hline & & HA & PP & UB & MS & \\
\hline \multirow[t]{5}{*}{ DR 2} & 1 & 26.67 & 13.33 & 6.67 & 0 & 53.33 \\
\hline & 2 & 33.33 & 20.00 & 0 & 0 & 46.67 \\
\hline & 3 & 40.00 & 33.33 & 0 & 0 & 26.67 \\
\hline & 4 & 40.00 & 26.67 & 0 & 0 & 33.33 \\
\hline & 5 & 33.33 & 26.67 & 0 & 0 & 40.00 \\
\hline \multirow[t]{5}{*}{ DRC 16} & 1 & 33.33 & 13.33 & 0 & 0 & 53.34 \\
\hline & 2 & 53.33 & 26.67 & 0 & 0 & 20.00 \\
\hline & 3 & 33.33 & 13.33 & 0 & 6.67 & 46.67 \\
\hline & 4 & 33.33 & 13.33 & 0 & 0 & 53.34 \\
\hline & 5 & 40.00 & 13.33 & 0 & 0 & 46.67 \\
\hline
\end{tabular}

Keterangan: $\mathrm{PP}=$ Phytophthora palmivora ; HA = Helopeltis antonii; $\mathrm{UB}=$ ulat bulu; $\mathrm{MS}=$ musang; ' 0 ' tidak ada serangan hama dan penyakit; Buah yang terserang oleh dua atau lebih hama dan penyakit maka nama patogen dipilih satu yang utama 
Tabel 5. Persentase kehilangan pada setiap fase perkembangan buah kakao klon DR 2 dan DRC 16 di Kebun Renteng, Jember, Jawa Timur

\begin{tabular}{lcccccc}
\hline \multirow{2}{*}{ Klon } & Ulangan & \multicolumn{3}{c}{ Kehilangan buah (\%) } \\
\cline { 3 - 7 } & $(\mathrm{n}=15)$ & Fase 1 & Fase 2 & Fase 3 & Fase 4 & Fase 5 \\
\hline DR 2 & 1 & 73.3 & 46.7 & 13.3 & 0 & 0 \\
& 2 & 46.7 & 33.3 & 0.0 & 0 & 0 \\
\multirow{2}{*}{ DRC 16 } & 3 & 86.7 & 20.0 & 20.0 & 20 & 0 \\
& 1 & 73.3 & 33.3 & 20.0 & 0 & 0 \\
& 2 & 73.3 & 40.0 & 33.3 & 20 & 0 \\
\hline
\end{tabular}

banyak, salah satunya karena meningkatnya jumlah cabang sekunder. Cabang sekunder sebagian besar berada pada ketinggian 101-200 cm dari permukaan tanah.

Sebaran bantalan buah (Tabel 6) dan serangan hama dan penyakit (Tabel 4 ) dapat dianggap sebagai faktor agronomi yang membatasi produktivitas tanaman kakao. Menurut Puslitkoka (2010), pemangkasan tajuk menstimulasi penambahan jumlah bantalan dan bantalan produktif karena batang dan bantalan buah terekspose pada sinar matahari dan suhu hangat $26-30{ }^{\circ} \mathrm{C}$. Tingginya jumlah bantalan, bantalan produktif dan buah kakao pada ketinggian 101-200 cm dari permukaan tanah diduga karena cabang lebih banyak terekspose pada sinar matahari, berbeda dengan bantalan buah pada ketinggian 0-100 cm yang cenderung terlindungi kanopi. Fakta ini menarik untuk dikaji lebih lanjut terkait durasi dan intensitas ekspose yang mampu menstimulus aktivitas bantalan buah.

Tabel 6 menunjukkan perbedaan jumlah dan produktivitas bantalan dari kedua klon pada umur tanaman berbeda. Jumlah bantalan dan jumlah buah pada klon DR 2 nyata lebih banyak pada umur 7 tahun dibandingkan 11 tahun, berkebalikan dengan klon DRC 16 (Tabel 6). Tanpa memperhatikan umur, pohon dari klon DR 2 memiliki jumlah bantalan 361-419 yang mampu menghasilkan buah 32-44 sedangkan klon DRC 16 dengan jumlah bantalan 359-400 memiliki 18-36 buah. Dengan demikian, pohon

Tabel 6. Sebaran buah pada dua umur tanaman kakao pada berbagai tingkat ketinggian batang di Kebun Renteng, Jember, Jawa Timur

\begin{tabular}{|c|c|c|c|c|c|c|}
\hline \multirow{2}{*}{ Umur (tahun) } & \multirow{2}{*}{ Peubah } & \multicolumn{4}{|c|}{ Jumlah per ketinggian } & \multirow{2}{*}{ Total } \\
\hline & & $0-50 \mathrm{~cm}$ & $51-100 \mathrm{~cm}$ & $101-150 \mathrm{~cm}$ & $151-200 \mathrm{~cm}$ & \\
\hline & & 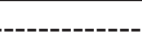 & ------ & - Klon DR 2 & ------------ & ----- \\
\hline \multirow[t]{3}{*}{7} & BTL & 13 & 56 & 138 & 212 & 419 \\
\hline & BTL produktif & 1 & 4 & 11 & 20 & 36 \\
\hline & Buah & 1 & 5 & 13 & 25 & 44 \\
\hline \multirow[t]{3}{*}{11} & BTL & 10 & 45 & 129 & 177 & 361 \\
\hline & BTL produktif & 1 & 4 & 9 & 12 & 26 \\
\hline & Buah & 1 & 6 & 10 & 15 & 32 \\
\hline \multirow[t]{3}{*}{7} & BTL & 13 & 55 & $\begin{array}{c}\text { Klon DRC 16 } \\
110\end{array}$ & 181 & 359 \\
\hline & BTL produktif & 0 & 2 & 6 & 7 & 15 \\
\hline & Buah & 0 & 2 & 7 & 9 & 18 \\
\hline \multirow[t]{3}{*}{11} & BTL & 12 & 51 & 137 & 200 & 400 \\
\hline & BTL produktif & 1 & 4 & 9 & 16 & 30 \\
\hline & Buah & 1 & 5 & 11 & 19 & 36 \\
\hline
\end{tabular}

Keterangan: $\mathrm{BTL}=$ Bantalan; BTL Produktif $=$ Bantalan yang menghasilkan buah; $\mathrm{Buah}=$ buah yang dapat dipanen; ukuran $\operatorname{contoh}=21$ pohon per klon 
klon DR 2 memiliki kemampuan berproduksi lebih besar dari klon DRC 16. Menurut Susilo (2014) DR 2 memiliki potensi produksi biji 2.16 ton $\mathrm{ha}^{-1}$ per tahun, sedangkan DRC 16 memiliki potensi 1.54 ton $\mathrm{ha}^{-1}$ per tahun. Berdasarkan potensi produksi, klon DR 2 diduga memiliki jumlah bantalan buah yang secara genetik lebih banyak.

\section{Analisis Panen}

Pemanen rata-rata memetik 33 buah kakao per siklus panen selama bulan Januari sampai Mei 2019, dengan ketepatan panen $57.58-88.46 \%$ (rata-rata $73.51 \%$ ) (Tabel 7). Jumlah buah muda terpanen per orang berkisar 3-18 buah. Pemanen memiliki alasan berbeda terkait adanya buah muda yang terpanen. Secara morfologi, ada perbedaan karakter buah yang menonjol antar klon yakni buah DRC 16 memiliki leher botol (bottleneck), sedangkan DR 2 tidak memilikinya. Menurut pemanen, leher botol merupakan salah satu tanda bahwa klon DRC 16 telah masak fisiologis (Gambar 1). Namun sebagian pemanen mengeluhkan sulitnya mengidentifikasi leher botol karena posisi buah terhalang oleh ranting. Akibatnya, sebagian pemanen khususnya yang berusia lebih dari 50 tahun tidak menjadikan leher botol sebagai kriteria panen. Hal ini diduga berkontribusi pada perbedaan ketepatan panen antar pemetik.

Tinggi badan pemanen dan ketepatan panen memiliki korelasi Pearson yang erat $\left(\mathrm{r}^{2}=0.623, \mathrm{P}\right.$-value $\left.=0.054\right)$, artinya tinggi badan pemanen cenderung memengaruhi ketepatan panen (Gambar 2). Semakin tinggi badan pemanen, ketepatan panen semakin tinggi. Pemanen memiliki ratarata tinggi badan $157.2 \mathrm{~cm}$ (Tabel 7) sedangkan kisaran tinggi tanaman kakao di lapang adalah $300-500 \mathrm{~cm}$. Adanya hambatan tinggi pemanen untuk menjangkau buah kakao, masih perlu elaborasi lebih lanjut karena pemanen sebenarnya telah dilengkapi alat panen yang dapat menjangkau semua ketinggian.
Pemanen bertanggungjawab memetik, memecah buah, mengambil biji dan menyerahkan biji kakao basah. Kemampuan pemanen dalam memetik buah matang menjadi kunci menghasilkan biji kakao bermutu. Buah yang masak fisiologis akan menghasilkan biji kakao berkualitas tinggi (Yusianto dan Firmanto, 2015). Selain leher botol, kriteria panen buah di lokasi studi adalah warna kulit buah dan nyaring ketika buah di ketuk. Buah tua berbunyi nyaring bila diketuk karena pulp biji yang sudah melunak. Sebagian pemanen sulit memastikan dengan mengetuk karena posisi buah $>200 \mathrm{~cm}$ dari permukaan tanah, yang tidak terjangkau karena hambatan tinggi badan. Kesulitan 'mengetuk' semakin besar khususnya di lokasi kebun dengan kontur lahan tidak rata.

Menurut pemanen kesalahan petik berdasar warna kulit buah sering terjadi. Penyebabnya warna buah pada ketinggian 300-400 cm sulit dipastikan karena silau atau pantulan sinar matahari, warna kulit buah terkadang berubah jika terekspose matahari berlebihan, dan serangan hama penyakit. Kesalahan paralaks kemungkinan juga dipicu usia pemanen (Tabel 8). Sebagian pemanen tertukar dalam identifikasi klon, karena buah fase 4 dan 5 dari klon DR 2 dan DRC 16 secara fenotipe sangat mirip (Tabel 3). Kemiripan warna buah kemungkinan karena jarak genetik keduanya dekat (Rubiyo, 2013). Sebenarnya, warna buah klon DR 2 tua (fase 5) adalah merah-jingga atau merahkekuningan, sedangkan klon DRC16 merah-jingga atau hijau-kekuningan. Pemanen cenderung menggunakan warna merah-semburat kuning atau merah-jingga sebagai indikator waktu panen bagi kedua klon, yang sebenarnya hanya tepat untuk DR 2 (Tabel 3). Rojas et al. (2020) menyarankan menggunakan kombinasi warna kulit, penampilan lekukan, dan kelunakan buah sebagai indikator kematangan buah. Tingginya kesalahan panen kemungkinan juga dapat terjadi karena adanya variasi klonal dari klon DR 2 dan DRC 16 yang mengakibatkan variasi morfologi dalam indikator

Tabel 7. Tingkat ketepatan panen buah kakao bulanan kaitannya dengan karakteristik pemanen di Kebun Renteng, Jember, Jawa Timur

\begin{tabular}{|c|c|c|c|c|c|}
\hline \multirow{2}{*}{$\begin{array}{l}\text { Kode } \\
\text { pemanen }\end{array}$} & \multirow{2}{*}{$\begin{array}{l}\text { Tinggi badan } \\
\qquad(\mathrm{cm})\end{array}$} & \multicolumn{3}{|c|}{ Jumlah per panen } & \multirow{2}{*}{$\begin{array}{c}\text { Ketepatan panen } \\
(\%)\end{array}$} \\
\hline & & Buah muda ${ }^{z}$ & Buah tua & Total & \\
\hline 1 & 170 & 5 & 37 & 42 & 88.10 \\
\hline 2 & 168 & 6 & 22 & 28 & 78.57 \\
\hline 3 & 160 & 18 & 26 & 44 & 59.09 \\
\hline 4 & 165 & 3 & 23 & 26 & 88.46 \\
\hline 5 & 141 & 11 & 20 & 31 & 64.52 \\
\hline 6 & 152 & 13 & 26 & 39 & 66.67 \\
\hline 7 & 156 & 4 & 20 & 24 & 83.33 \\
\hline 8 & 148 & 14 & 19 & 33 & 57.58 \\
\hline 9 & 157 & 11 & 22 & 33 & 66.67 \\
\hline 10 & 155 & 5 & 23 & 28 & 82.14 \\
\hline Rata-rata & 157.2 & 9 & 24 & 33 & 73.51 \\
\hline
\end{tabular}

Keterangan: Data rata-rata bulanan $(n=5) ;{ }^{2}$ Buah dikatakan muda bila saat dikupas antar biji masih sulit dipisahkan 


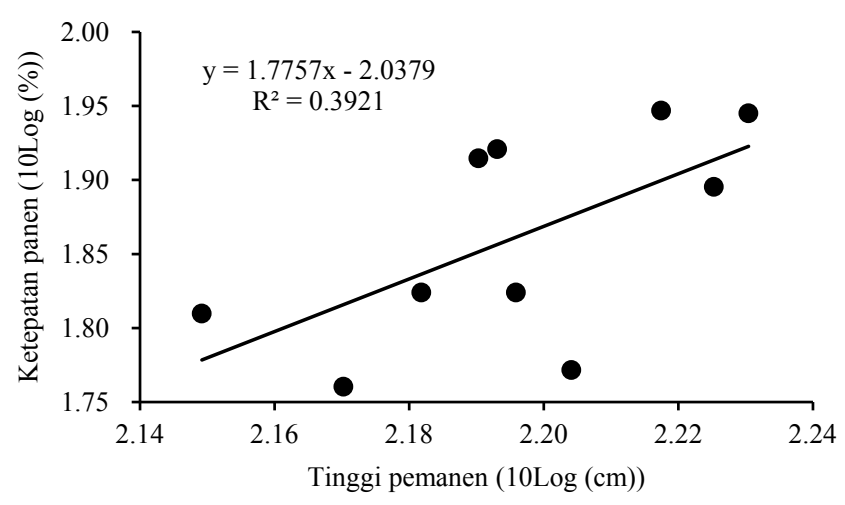

Gambar 2. Korelasi tinggi badan pemanen dengan ketepatan panen buah kakao di Kebun Renteng, Jember, Jawa Timur. Data ditransformasi $\log (10)$

panen. Namun variasi klonal pada kedua klon tersebut masih spekulatif, karena menurut Susilo (2014), DR 2 dan DRC 16 memiliki karakter menyerbuk sendiri dan self compatible. Tetapi dugaan ini membutuhkan pembuktian lebih lanjut.

Ketepatan panen juga dipengaruhi umur pemanen (Tabel 8). Pemanen berusia muda ( $<50$ tahun) memiliki ketepatan panen nyata lebih tinggi dibandingkan dengan usia tua ( $>50$ tahun), yakni berturut-turut $81.03 \%$ dan $66.00 \%$. Ada kecenderungan pemanen berusia $<50$ tahun lebih teliti dalam memetik buah yang tua dibandingkan dengan pemanen berusia $>50$ tahun. Ada dugaan bahwa faktor usia juga memengaruhi ketajaman penglihatan pemanen sehingga memengaruhi ketepatan panen.

Penelitian ini mengungkap faktor agronomis dan nonagronomis yang berkontribusi langsung pada produktivitas tanaman kakao mulia di lokasi studi. Faktor teknis terkait efektivitas pemanenan yang merupakan faktor nonagronomis sudah saatnya dikaji dalam rangka meningkatkan produksi tanaman kakao misalnya melalui seleksi pemanen berdasarkan usia dan tinggi badan. Halaliah et al. (2019) mengidentifikasi delapan penyebab tidak tercapainya mutu kakao mulia yakni cuaca ekstrim, kematangan biji, faktor pemeliharaan, sortasi, kotoran biji basah, evaluasi mandor, ketrampilan mandor dan usia tenaga kerja dengan kontribusi berturut-turut $20.0 \%, 16.7 \%, 13.3 \%, 13.3 \%, 10.0 \%, 10.0 \%$, $10.0 \%$, dan $6.7 \%$. Peningkatan kecermatan pemanen juga merupakan faktor penting yang menentukan kualitas biji dihasilkan (Rinaldo dan Chozin, 2016). Faktor gender dan usia telah terbukti memengaruhi keberhasilan pemangkasan tanaman kakao (Angela dan Efendi, 2015).

Tabel 8. Pengaruh usia pemanen terhadap ketepatan panen buah kakao di Kebun Renteng, Jember, Jawa Timur

\begin{tabular}{lc}
\hline Usia pemanen (tahun) & Ketepatan kualitas panen (\%) \\
\hline$<50$ & $81.03 \mathrm{a}$ \\
$>50$ & $66.00 \mathrm{~b}$ \\
\hline
\end{tabular}

Keterangan: Huruf berbeda di belakang angka menunjukkan nyata berbeda menurut uji t-student pada taraf uji $5 \% ; \mathrm{n}=$ 5 orang

\section{KESIMPULAN}

Produksi kakao edel dipengaruhi oleh jenis klon, posisi buah pada pohon, serangan hama dan penyakit, dan karakteristik pemanen khususnya umur dan tinggi badan. Buah kakao klon DR 2 membutuhkan 21-24 minggu untuk matang fisiologis dan DRC 16 membutuhkan 19-22 minggu. Efektivitas panen buah kakao dipengaruhi oleh posisi buah, sebaran buah kakao pada batang, serangan hama dan penyakit, jenis klon, karakteristik panen, dan usia pemanen. Sebaran posisi buah merupakan faktor fisiologi dimana semakin ke atas semakin besar jumlahnya. Posisi buah yang tinggi menyebabkan pemanen dengan keterbatasan tinggi badan sulit menjangkau dan memastikan tingkat kematangan buah menggunakan kriteria warna kulit dan ketukan. Penelitian menyimpulkan perlunya mengatur tinggi pohon sehingga posisi buah dalam jangkauan pemanen.

\section{UCAPAN TERIMAKASIH}

Terimakasih kepada Pimpinan Kebun Renteng Jember Jawa Timur dan Direksi PTPN XII yang memfasilitas penelitian ini. Tulisan ini didedikasikan kepada almarhumah Dr Nurul Khumaida atas ide-ide, infografis dan ketelitiannya dalam formulasi data dan tulisan. Doa kami semua menyertai semoga mendapat tempat terbaik disisi Allah Subhanahu Wata'ala.

\section{DAFTAR PUSTAKA}

Al-Ghozy, M.R., A. Soelistyo, H. Kusuma. 2017. Analisis ekspor kakao Indonesia di pasar internasional. J. Ilmu Ekonomi 1: 453-473.

Angela, D. Efendi. 2015. Pengelolaan pemangkasan tanaman kakao (Theobroma cacao L.) di Cilacap, Jawa Tengah. Bul. Agrohorti 3:285-293.

Anna, O.N. 2011. Pengelolaan panen dan pascapanen tanaman kakao (Theobroma cacao L.) di Kebun PT Rumpun Sari Antan 1, Cilacap, Jawa Tengah. Skripsi. Fakultas Pertanian. Institut Pertanian Bogor.

Atmadja, W. 2003. Status Helopeltis antonii sebagai hama pada beberapa tanaman perkebunan dan pengendaliannya. J. Penel. Pengembangan Pert. 22:57-63.

BPS [Badan Pusat Statistik]. 2018. Statistik Kakao Indonesia 2017. Badan Pusat Statistik Indonesia.

Engels, J.M.M., B.G.D. Bratley, G.A. Enriquez. 1980. Cacao descriptors, their states and modus operandi. Turrialba 30:209-218.

Halaliah, R., R. Wibowo, A. Supriono. 2019. Strategi peningkatan produksi mutu biji kakao mulia di PTPN XII Kebun Renteng Kabupaten Jember. Berkala Ilmiah Pert. 2:66-71. 
Kurniawati, A., A. Wachjar, A.T. Sinaga. 1998. Pengaruh pupuk boron (B) dan seng ( $\mathrm{Zn}$ ) terhadap layu pentil dan buah kakao (Theobroma cacao L.) yang dapat dipanen. J. Agron. Indonesia 26:16-21.

Matitaputty, A., H.R.D. Amanupunyo, W. Rumahlewang. 2014. Kerusakan tanaman kakao (Theobroma cacao L.) akibat penyakit penting di Kecamatan Taniwel Kabupaten Seram Bagian Barat. J. Budidaya Pert. 10:6-9.

Prawoto, A.A. 2014. Dinamika pertunasan, layu pentil, dan ketepatan taksasi produksi beberapa klon kakao. Pelita Perkebunan 30:100-114.

PTPN12 [PT Perkebunan Nusantara XII]. 2019. Kakao edel, finest cocoa variety. Tersedia di: https://ptpn12. com/2019/07/09/kakao-edel-finest-cocoa-variety. [akses 10 Juli 2020].

Puslitkoka [Pusat Penelitian Kopi dan Kakao Indonesia]. 2010. Buku Pintar Budidaya Kakao. PT Agromedia Pustaka, Jakarta, ID.

Randriani, E., Dani, I. Sulistiyorini. 2014. Keragaan tanaman kakao (Theobroma cacao L.) hasil perbanyakan embrio somatik di Kebun Percobaan Pakuwon. Sirinov 2:199-206.

Rinaldo, R., M.A. Chozin. 2016. Manajemen sortasi dan pemecahan buah kakao (Theobroma cacao L.) di Jawa Tengah. Bul. Agrohorti 4:210-214.

Rohman, F., A. Wachjar, E. Santosa, S. Abdoellah. 2019. Humic acid and biofertilizer applications enhanced pod and cocoa bean production during the dry season at Kaliwining Plantation, Jember, East Java, Indonesia. J. Trop. Crop Sci. 6:153-163.
Rojas, K.E., M.C. García, I.X. Cerón, R.E. Ortiz, M.P. Tarazona. 2020. Identification of potential maturity indicators for harvesting cacao. Heliyon 6: e03416.

Rubiyo, Siswanto. 2012. Peningkatan produksi dan pengembangan kakao (Theobroma cacao L.) di Indonesia. Bul. Ristri 3:33-48.

Rubiyo. 2013. Inovasi teknologi perbaikan bahan tanam kakao di Indonesia. Bul. Ristri 4:199-214.

Santosa, E., G.P. Sakti, M. Z. Fattah, S. Zaman, A. Wachjar. 2018. Cocoa production stability in relation to changing rainfall and temperature in East Java, Indonesia. J. Trop. Crop Sci. 5:6-17.

Saputra, A. 2015. Faktor-faktor yang mempengaruhi produksi kakao di Kabupaten Muaro Jambi. J. Penelitian Universitas Jambi Seri Sains. 17:1-8.

Sari, D.M., A. Fariyanti, N. Tinaprilla. 2017. Analisis efisiensi teknis perkebunan kakao rakyat di provinsi Lampung. J. Tan. Industri Penyegar 4:31-40.

Susilo, A.W. 2014. Bahan tanam unggul kakao. Materi Pelatihan Fasilitator Utama, Jember 15-26 September 2014. Tersedia di: http://www.cocoasafeindonesia. id/wp-content/uploads/2015/03/Bahan-Tanam-danPerbanyakan.pdf.

Tutiliana. 2014. Aplikasi ZPT auksin, seng, dan boron untuk mengendalikan layu pentil (cherelle wilt) pada tanaman kakao (Theobroma cacao L.). J. Edukasi Sains Biol. 3:3-6.

Yusianto, Firmanto. 2015. Kakao: Sejarah, Botani, Proses Produksi, Pengolahan, dan Perdagangan. Gadjah Mada University Press, Yogyakarta, ID. 